\title{
From Brigades to Blogs: Environmentalism Online in Slovakia 20 Years after the Velvet Revolution*
}

\author{
EDWARD SNAJDR** \\ City University of New York
}

\begin{abstract}
This article examines aspects of contemporary Slovak environmental activist discourse in the digital realm of blogging and cyberspace. It explores this subject by first comparing volunteer brigades and samizdat writing from the late communist period with present digital forms of environmentalism in the new millennium. Current environmental blogs are then analysed according to material, substantive, and discursive aspects as these suggest obstacles and benefits to promoting environmentalism in the wake of political transformation. In examining this issue in one Central and East European context, the paper aims to raise broader questions regarding both research on environmental behaviour and policy in post-socialist Europe as well as the relationships between culture, political consciousness and technology in an age of globalisation.
\end{abstract}

Keywords: environmentalism, ecological activism, internet, blogging, postcommunism, Slovakia

Sociologický časopis/Czech Sociological Review, 2012, Vol. 48, No. 3: 493-508

\section{Introduction}

The setting is Slovakia-you sit in a small flat in a gray, concrete high-rise in Bratislava. You have just finished writing something critical about the government. You have been toiling on this piece for some time: editing, elaborating, re-editing, and cutting. Your writing is not overtly critical of the current policies of the

\footnotetext{
* Acknowledgements. A version of this article was presented as a paper at the 40th National Convention of the American Association for the Advancement of Slavic Studies (now ASEEES) in Boston on 21 November 2009. The author would like to thank Krista Harper, Jonathan Larson, and David Doellinger for their helpful comments. The City University of New York and the Professional Staff Congress (PSC-CUNY) provided a grant in support of research for this article. Some parts of this research were made possible with the support of the National Science Foundation Doctoral Dissertation Improvement Grant, Cultural Anthropology Program, SBR\# 9412715. The author would like to thank Petr Jehlička, Marek Skovajsa, Michael L. Smith, and two anonymous reviewers for their helpful comments on earlier versions of this article. Special thanks to Daniela Luka Snyder for her assistance with the translation of some of the Slovak materials cited.

** Direct all correspondence to: Edward Snajdr, Department of Anthropology, John Jay College, City University of New York, 899 Tenth Avenue, Room 9.63.19, New York, NY 10019, USA, e-mail: esnajdr@jjay.cuny.edu.
} 
present regime. In fact, it is mostly allegory, and (you hope) a little bit funny. You wrote the piece for yourself, of course, because it is about things that you personally believe in. If society shares your views, you feel as if they are reluctant to voice them in these difficult times. Nevertheless, you boldly show your writing to your friends. But you have no official publisher. On the contrary, you circulate your work as a form of self-publication-the now familiar Slavic word for this is 'samizdat'.

Your writing certainly resembles what Komaromi [2004] has recently concluded from her archival study of Soviet period samizdat. It is 'a particular medium ... characteristically wretched and [which] frequently feature[s] mistakes and corrections' [ibid.: 603]. As your friends read your piece they add their own commentary. Komaromi calls this process 'the nature of the samizdat system [which] complicate[s] the notion of a true "message" and an individual author" [ibid.: 604]. In her assessment of the material aspects of samizdat, Komaromi recognizes Derrida's concept of the written trace in self-made texts. Samizdat 'implie[s] a certain amount of ambiguity or "play" between the physical form and the ideal content, between the signifier and the signified' [Komaromi 2004: 604]. ${ }^{1}$ We can thus understand samizdat as more than simply a political text produced during a period of repression. Samizdat is also a social act. It is a process of co-creation among writer and readers. It forges a discursive community among citizens and ideas.

But the Slovak piece I am referring to above is not from the communist period. It is not 1979 Bratislava, but rather thirty years later in 2009. The work in question is by a man named Juraj Rizman, an environmental activist, professional photographer, and self-identified blogger. His piece, titled 'Energetická a plynárenska kríza-za čo môže Vláda SR?' (The Energy and Gas Crisis-Is the Slovak Government to Blame?) was posted on 1 August on the blog 'aktualne.centrum. sk'. In the first 24 hours that Rizman posted his blog, over 80 people responded with commentary. By the end of October, the work had received over 10800 page views.

Is Rizman's text indicative of the kinds of political discourse at play in the present period of post-socialist democracy in Slovakia? Has environmentalism actually transformed from volunteer brigades and samizdat publishing to a more sophisticated and global internet-based activism? Or are blogs simply a new form of publicising long-standing environmental issues that may actually limit the public reach of environmental discourse in a post-totalitarian cyber world? Contemporary scholars and researchers certainly remember how computer technology and the world-wide web transformed alongside our own academic development. One might recall how one's personal engagement with this transforming technology compared to those of other colleagues and/or research

\footnotetext{
${ }^{1}$ Komaromi notes that "this spirit of "play" in all senses strongly infused samizdat from its inception. In using the term samizdat, [the poet Nikolai] Glazkov was parodying the acronyms of official Soviet publishing houses like "Gosizdat", "Voenizdat", and so on' [Komaromi 2004: 605].
} 
participants in Central and East Europe. At one time, CEE represented the classic 'digital divide' between the socialist world and Western democracy. Both friends and fellow scholars on both sides of the Danube had to contend with vast differences in hardware, amounts of memory and at times painfully slow or surprisingly fast processors and modems. And yet so much has changed since my own field research in the mid-1990s in Slovakia-both here and over there.

In this article I want to explore a few discursive aspects of contemporary Slovak environmentalism by comparing it with its older formats from the late communist-era and by considering the implications of its present appearance in the digital realm of the new millennium. After a brief discussion of volunteer brigades and environmental samizdat in the communist period, I focus on environmentalism's move to the digital realm and on the status of critical environmental discourse in the form of the rapid growth of blogging in Slovakia. Using data from blogs themselves, I examine the similarities and differences between blogs, the problematics of this mode of discourse, as well as how this form of activism provides, if not a 21st century analogy to samizdat, then a technologically mediated form of discourse that mimics it but is also quite limited by its own medium. Although my effort is preliminary, I hope that in examining this issue in one Central and East European context, I am able to raise several broader questions regarding both research on environmental behaviour and policy in post-socialist Europe as well as the relationships between culture, political consciousness, and technology in an age of globalisation. Ultimately, in comparing the past with the present with both technological and cultural contexts in mind, I hope to shed light on the dilemma of public life in current democracies, including Central and East European countries, whereby the freedom to speak about and to represent a cause is no doubt present, but is also relying increasingly on modes of digital communication which may be limiting and constrained as sites of social experience and political action.

\section{From brigades to Bratislava/nahlas}

Before comparing environmentalists in the past with those of the present, though, I need to briefly summarise the quite grassroots character of Slovak environmentalism during the late communist period and how both volunteerism and self-publishing efforts developed in tandem to define and publicise ecological problems. Throughout the 1970s and 1980s, individuals interested in ecology or conservation could join interest groups within the scope of the Slovak Union of Nature and Landscape Protectors (SZOPK). Volunteer projects were modest and limited to local areas, for example, the prevention of erosion, observing fauna and collecting flora in specific habitats, and preserving folk architecture in rural landscapes. These activities usually took place as weekend brigades or group excursions during vacation time and they garnered little publicity and even less controversy [Snajdr 2008]. 
Alongside this volunteer conservationism, individuals began to experiment with writing about the environment beyond the framework of official venues such as academic journals and state-sanctioned magazines. Somewhat divergent from Komaromi's conclusions about the universal patterns and qualities of samizdat, however, my experience with Slovak forms of samizdat suggest that beyond the 'wretched' typescript and poor printing quality, people who got their hands on these sorts of texts treated them with a reverence and care fit for ancient scrolls. As an example, take the samizdat work, 'Cemetery Stories', by the environmental activist-dissident Ján Budaj, which exposed the local government's controversial removal of gravestones from a Bratislava cemetery. Copies of the text were carefully stored in folders and large envelopes-tucked away in bottom desk drawers as if this document were a form of currency.

Slovakia's dissident movement in the early 1980s consisted of only a handful of writers and religious activists. Perhaps more so than literature, Catholicism provided many with a source for personal and spiritual opposition in the form of the Secret Church and its not-so-secret displays of religiosity [Doellinger 2002]. Aside from this religious movement, and in addition to his samizdat writing, Ján Budaj created in the 1980s what he called a campaign of Cultural Fiction. Around the city of Bratislava, Budaj posted fantastical public displays, such as authentic-looking advertisements announcing fake public concerts by ABBA and Bob Dylan [Wright 1990]. Of course these bands were not allowed to perform in Czechoslovakia, and the implicit critique that these fake posters launched against the regime created a spatial and literary experience for public consumption-that is at least during the period before the police would tear them off the sides of buildings and lampposts. Budaj's struggle against the regime was an act of constructing self-created space and this approach was inspirational for the nascent environmentalist community in Bratislava. This community had begun to develop its own self-created space in the cultivation of brigade culture. The Bratislava branch of SZOPK began to treat the brigade as a form of public meeting. It was an opportunity for amateur environmentalists, as well as for technical and academic experts, to share their ideas and concerns about the environment, pollution, and policy in the safety of the relatively isolated wilderness settings of brigade activities. This culture also welcomed members such as Budaj, who found in the organisation an openness towards alternative viewpoints and a desire to share their work and views with the public. It was a formula that could be applied to the samizdat format to great effect.

In 1987, under the leadership of Budaj and Mikuláš Huba, the Bratislava branch of SZOPK published Bratislava/nahlas, a report vividly describing the terrible ecological problems plaguing Slovakia's capital city. The title was an allusion to Gorbachev's recent Soviet reforms. ${ }^{2}$ In keeping with the theme of glasnost, the report's twenty-three authors identified themselves on the inside cover, and also

${ }^{2}$ Nahlas, the Slovak adverb 'loudly', invoked the Soviet leader's policy of increasing openness or glasnost (voicing). 
listed the names of professionals that they had consulted. The sixteen chapters of the report were divided into three parts. Parts One and Two covered conditions in the natural environment, including air, water, land, radioactivity, noise pollution, and the urban environment, the condition of industry and transportation and buildings. Part Three described the situation facing the social environment including social and cultural infrastructure, services, health, and social groups. With each chapter focusing on a particular aspect of pollution and health, the narrative identified Bratislava's well-known streets, neighbourhoods, parks, and industries and unveiled a comprehensive portrait of a city and its people in an unfolding environmental crisis. In the samizdat spirit, the authors never explicitly implicated the regime as responsible for the maladies it presented. Instead, the text electrified the public by simply describing reality. As the text spoke with the various voices of the city's professional community, it transcended any one perspective or sector. The self-published report took a holistic and ethnographic approach, covering all angles of the experience of the environment in the capital city and examining these issues in substantial depth and through personal experience.

Now Bratislava/nahlas might not really fit the classic definition of samizdat. The text was officially—and technically legally—published as the minutes of a meeting. Yet, following research on samizdat that recognises diverse types of self-produced writing [Johnston 1999], including 'official' and 'semi-official' forms, one can say that the Union's environmental report used the framework of legitimate discourse to subvert the system. If we follow other research on samizdat as a social phenomenon utilising writing as domain of 'free thought' in the Soviet experience [Joo 2004], we can see how Bratislava/nahlas clearly shares important similarities with self-published texts of the earlier Soviet period. As Darnton [1989] notes, reading is an act with which a role is imposed on you by the text, and in this sense samizdat poignantly captures the schizophrenic and conflicting character of the literary experience as a political act under the yoke of totalitarian power [Yakushev 1975].

Indeed, the regime was caught completely off guard by Bratislava/nahlas and it relied on the usual tactics of totalitarianism, including attempts to interrogate the authors and to confiscate the critical text. But individual names could not be matched directly to particular chapters, so the authorities went after Budaj, the document's official publisher, and several key conservationists who had put their name to the contents. In fact its diffuseness and physical portability kept it from the clutches of the regime. SZOPK had made over 3000 copies of the document which were impossible to confiscate and which quickly circulated through personal networks. One activist described how he passed on a copy of Bratislava/nahlas to friend: 'It was wrapped in brown paper, like a present', he recalled. 'I treated the document like it was a fragile vase. But I was absolutely nervous and convinced that the secret police were watching us. ${ }^{\prime 3}$

${ }^{3}$ Quoted from the author's interview with Peter Spörer on 26 June 1995 in Kvačianska dolina, Slovakia. 
So even in its semi-official samizdat form, Bratislava/nahlas was politically deviant and therefore dangerous. On the one hand people were in danger by merely possessing the text. On the other hand, individuals desired, coveted, protected, and widely disseminated these self-made works. Even though the authorities had been watching and seeking control of the document, it turns out that the public was watching too. And in the ensuing years of 1988 and 1989, the Union's official magazine, Ochranca prírody (Nature Protector), morphed into a samizdatlike journal, attracting a range of dissident and critical personalities who published subversive writing under the umbrella label of nature protection.

As the regime collapsed in 1989, open protest quickly became an accessible form of political action and thus an important discursive tool with which to reach the public for environmentalists and for many other interest groups and movements. Freedom of expression was not only possible, it was embraced by a wide range of political movements, organisations, and supporters of diverse causes [Bútora, Bútorová and Rosová 1991]. At the same time, many of the supporters of SZOPK in Bratislava found their critical voices in other areas previously offlimits to open activism such as political campaigning, journalism, educational reform, and market privatisation efforts. Volunteer brigades continued to provide environmentalism with a collective but more overtly recreational endeavour as new organisations were allowed to emerge and grow, and this gave activists with more specific and explicit vehicles of public awareness and environmental consciousness and hence with new discursive powers, such as protests, public meetings, and the open press [Snajdr 1998]. Samizdat as a medium and as a discursive technology thus essentially died off with the old regime.

\section{Slovak cyber-protests in the new millennium}

Since the Velvet Revolution, Slovak environmental activism has experienced many changes - on one hand becoming much like Western issue-based groups and on the other hand it still grapples with the traditions, tendencies, and perspectives of life under the old regime. Both dimensions have figured in the pursuit of prominent and not-so-prominent ecological concerns, such as the Gabčíkovo Dam, the construction and renovation of nuclear power plants, and the management of scarce water resources throughout the region. As Fagan [2004] has noted for the Czech Republic, environmental groups shifted rapidly from conservationism, to political challengers of the old regime, to organisations straddling international and local identities and issues. One of the most challenging aspects to Czech environmentalism has been a financial dependency on Western funding sources, and the implications that this dependency has on nurturing and maintaining a strong influence among local communities. The situation in Slovakia is no different, and the paradox of fighting for the environmental rights of local villages with grants and technical assistance from abroad remains among many organisations [Snajdr 2008]. Perhaps Juraj Podoba [1998] has best articulated the conundrum of Slovak 
environmentalism's special experience, transitioning first from communism and then out of the Mečiar era as a rejection of 'green velvet', in which the motivation for activism becomes usurped by the identity politics of both communism and nationalism - an experience not suffered by the movements in Hungary or the Czech Republic. ${ }^{4}$ Slovakia's environmental movement was so integral to the civic and non-violent opposition against the regime that it appeared poised to play a primary role in transition politics, a 'greening' so to speak of the political transformations started with Czechoslovakia's Velvet Revolution. Yet Slovakia's rapid swing towards identity questions quickly overshadowed what were once considered urgent social and political issues including pollution, public health and energy safety. The symbols of environmental degradation such as Gabčíkovo were quickly reinterpreted as sites of national achievement. ${ }^{5}$

Accompanying this development has been the rapid emergence of new computer and media technologies. Research about the internet and the social and cultural aspects of technology and cyberspace are really only now emerging in the field of anthropology [Malaby 2009; Wesch 2007] and in other areas of social science [Katz and Rice 2002; Hampton and Wellman 2003]. Bach and Stark's [2003] work on the relationship between NGOs in Central and East Europe and a growing IT network suggests new possibilities for organisational and social transformations that at the same time present the challenge of balancing activist agendas with business models of efficiency and accountability. Ludrovská [2008] has recently studied the rapidly growing blogosphere in Slovakia. She argues that Slovakia's specific political experience with media and governance in the aftermath of the collapse of communism has directly influenced and encouraged a large and widespread blogging community in the country. More so than in other CEE states, Slovakia's legacy of the Mečiar period, and the historically constrained and politically dominated print media and television stations, enriched the soil of digital communication, amateur journalism, and citizen blogs. Some striking data provided by Ludrovská is the fact the Slovakia boasts some 1.8 million internet users in a country whose population still hovers around 5.5 million [Ludrovská 2008: 62]. At the same time, bloggers and their audiences cluster mainly around major urban centres such as Bratislava (which accounts, according to Ludrovská, for $45 \%$ of the weblog population in the country). The pioneers of the blogging movement got their start in the rise of new media. For example, the newspaper SME launched the first blog portal in Slovakia in 2004 [Ludrovská 2008: 28] and other papers followed suit. Driving the development and popularity of the blog format in Slovakia are several web portals that feature a range of issues including news, entertainment, media, the economy and of course politics. Some examples of popular blogs include 'www.field.sk' and 'www.kavicky.blogspot.com'.

\footnotetext{
${ }^{4}$ Huba [2003: 102] also describes the specific rise and fall of the political status of SZOPK members as an outsider to a leading political force and back to outsider status in the dynamics of late communism and post-communism in the Slovak Republic.

${ }^{5}$ Snajdr [2008: 98-110] also describes this process of shifting identity politics with respect to ecological issues in the early 1990s.
} 
Like other Slovaks, environmentalists have tried to adapt to the world of cyberspace and to utilise new digital formats such as the blog to promote themselves and their agendas. ${ }^{6}$ One need only visit the websites of several environmental organisations active in Slovakia to gain a sense of the increasingly digital presence of the current movement in Slovakia and the various ways that the internet has been utilised by it. ${ }^{7}$ For instance, on 'www.greenpeace.org/Slovakia' one can trace the long and active tenure of Greenpeace Slovakia, a group that formed in Slovakia in the early 1990s along with Za matku Zem (For Mother Earth). Greenpeace Slovakia's website promotes their sustained protest campaign targeting the Mochovce Nuclear Power Plant in Central Slovakia, a campaign that they have fought for over two decades in partnership with Za matku Zem [Snajdr 1998]. Greenpeace Slovakia has also devised strong theatrical demonstrations and public performances against the environmental abuses of multi-national corporations such as Nike and Volkswagen. The organisation's portal also links the visitor to a comprehensive record of action - through vivid photo archives-that prove the resilience and adaptive efforts of local activists in keeping messages focused and at the forefront of the public experience.

A visit to Za matku Zem's website ('www.zmz.sk') provides access to an enormous amount of information both about the group and its activities and actions in the realm of several campaigns, such as wind energy and other alternative sources, ecology camps, public forums, and about the environment and its problems around the globe. This very local organisation, which began in the mid-1990s, has matured into a sustained collective of educated professionals and activists who maintain an international network of communication, knowledgebuilding, public relations and lobbying.

The internet has also helped to link environmental organisations together both with respect to each other and to the general public interested in environmental issues. For example, 'www.environmentalpartnership.org/slovakia', the website of the Environmental Partnership for Sustainable Development's (EPSD) Slovak page, yields a wide range of links to other environmental organizations and partners of the EPSD throughout Central and East Europe and beyond. Priatelia Zeme, the Slovak branch of Friends of the Earth International (FOE), which is partnered with Juraj Zamkovský's Centre for Public Advocacy (CEPA) and with VLK (Wolf), an association of forest conservationists, has a comprehensive website (www.priateliazeme.sk) that includes the usual information for visitors (people, news, activities, publications/documents, and information about joining the group). It also is linked to the main FOE website which connects a visitor to all of the FOE branch organisations in over 30 countries. Even SZOPK, the

\footnotetext{
${ }^{6}$ Elsewhere I compare the very different approaches of Slovak and Hungarian environmental movements as these emerged from significantly unique political and cultural moments and ecological issues [Snajdr 2009, 2008]

7 The author would like to thank two anonymous referees for suggesting an elaboration of this point.
} 
volunteer conservation organisation and network so popular under late communism has a central website (www.szopk.sk), on which it links members to news, articles, and various activities of over 40 local branches of the conservation union around the country.

However, both the SZOPK and Priatelia Zeme websites, as well as Za matku Zem's, only provide information in Slovak and thus, despite links to organisations abroad, are effectively limited to the Slovak-speaking community. ${ }^{8} \mathrm{Al}-$ though a digital divide may have been closed, a linguistic divide still restricts the discursive communities of digital activism and political action to the national level. And these sites are limited in other ways. For example, Priatelia Zeme's media banner contains no information as of January 2012. While SZOPK's website provides digital links to two local SZOPK groups, ZO SZOPK Bocian, Moldava nad Bodvou, and ZO SZOPK Mineopterus in Bratislava, there are other inactive websites from the past, such as 'www.spes.sk', which appear when utilising a search engine such as Google, that have not been updated since 2003.

Indeed, considering these few examples above, environmentalism in Slovakia has certainly gone 'online' in so many ways and with the various problematics and possibilities one might find in on-line networks and communities linked with other issues, social movements, industries, and interest groups. It is important to note, however, that this new format for promoting ecological activism and for linking individuals in a digital community has not necessarily led to the creation and articulation of new environmental issues. The same primary environmental concerns and struggles continue to shape the landscape of Slovakia's post-communist society, as evidenced from themes taken from the websites I have just described above. For example, on Za matku Zem's website, the organisation continues to battle against the country's dependence on nuclear energy. This is also the case for Greenpeace Slovakia which began its work in Slovakia as an anti-nuclear movement. Finally, the organisations partnered with Priatelia Zeme-CEPA have also maintained a steady course of protest, lobbying, and raising public awareness regarding waste disposal, public health, and the role of corporations in the proliferation and mismanagement of natural and human resources. If there has been a new development in the discursive agenda of these groups it has been the appearance and emerging articulation of the issue of climate change, a theme that is found in various forms on the websites of all three organisations. Alongside these more progressive groups, SZOPK remains a more conservative and conservationist-oriented network of eco-groups, with a particular concern for public education.

How then are issues about the environment promoted and circulated in this new digital medium of the world of cyberspace? I want to focus the remainder of

\footnotetext{
${ }^{8}$ It is important to note that the Slovak government including the Government Office, the President, the National Council and the various government ministries (including the Ministry of the Environment) all have websites in both Slovak and English.
} 
this article on two specific portals in which the Slovak environmental community has participated and through which it continues to grow in order to compare how environmental discourse is produced and circulated through one form of self-publication in the current moment, and to suggest important questions that digital technology raises in terms of social movements and collective engagement with political issues in a contemporary globalising world that are quite different from the problems faced by environmental discourse in the past regime.

\section{Blogs as a new type of samizdat}

The first portal, called 'www.aktualne.centrum.sk', is a for-profit outfit featuring a wide-range of content including media, politics, and social and personal issues. It receives over 43000 page views per day and contains pop-up advertising and a host of links and resources to other internet-based businesses. Included on the portal's roster of bloggers are Juraj Rizman, the young environmental activist whom I introduced to you earlier and Mikuláš Huba, a geography professor and past leader of the Slovak Union of Nature and Landscape Protectors. By the way, the Catholic politician and former Prime Minister Ján Carnogurský is also a regular blogger on the site.

The other portal is called 'www.changenet.sk' and is focused on the nonprofit and activist community in Slovakia. Surman [2002] reports that Slovak internet activity started as literally 'trickles' of information, yet quickly grew to torrential proportions. But the increase in users and visitors understandably correlates with specific political events, such as the 1998 national elections. Interestingly, Surman also acknowledges that the portal's content and tone have been largely shaped in the first half of the decade by none other than Juraj Rizmanthe site's senior editor during this period. Yet since 'www.changenet.sk' remains a non-profit internet operation, the portal is still quite small when compared to the privately-run 'www.aktualne.centrum.sk'. Presently 'www.changenet.sk' receives an average of only 415 page views per day.

If we follow Komaromi [2004] and examine these examples of environmental blogs from a material point of view, we quickly see that they share some discursive structural similarities with the samizdat writing of the Soviet period. A blog is crafted from very diverse structural aspects of text-making that give it its own home-made feel and appearance. A posting initially appears as a model of compositional structure-with the primary text following a title and a by-line. But below this usually follows a string of 'responses' by readers of the blog. Some of these may be quite lengthy, but most are short and choppy-amounting to only a couple of sentences which often seem hastily written. Thus the medium of blogging-like the medium of samizdat-creates, in a way, a rather unique genre of writing. Similar to the way samizdat literature was produced and then circulated as a text-a circulation that by its very existence created a discursive community, 
a blog moves from a single author's organised exposition to an increasingly chaotic conversation recorded as written text-a sort of call-and-response format one might find among a crowd of protesters.

The crowd-like character of this co-constructed text is reinforced by the informal manner of identification of respondents. For example, in Rizman's blog on 'www.aktualne.centrum.sk' about energy and the Slovak government, we find that people posting comments provide only an online name. No one gives out their email address unless they so choose. Thus most readers comment on issues without revealing their identities, forming a sort of anonymous voice.

Also interesting is the pattern of responses in terms of time between posting and commentaries. Each remark by a reader is accompanied with a response time and date. Thus it is easy to track patterns of reading and replying to a text. It is etched onto the blog format itself. For example, over the course of three days, Rizman's blog received the majority of reader response. By the end of the month, replies had stopped. Like the samizdat text, then, a blog 'lives' within the community - and changes as it is read and circulated.

In looking at the present cyberworld however, we also find that Darnton's concept of reading as social action, whereby one must consider a 'reader' to be a social actor in a political field [Darnton 1989], helps us to distinguish the unique character of blogging as a type of samizdat that is produced in an open society. Thus, unlike Bratislava/nahlas and the late-1980s issues of Ochranca prírody which created a collective authority as a counter to official authority, the blog format seems to undermine the goal of cultivating a unified voice. For example, on the 'www.changenet.sk' portal is a posting from June of 2007 by the NGO Our Tatras about the logging of fallen timber in Slovakia's Tatra Mountains National Park. The main text is a proclamation outlining the group's rejection of a government decision to allow the clearing and selling of trees damaged by a storm that hit the park in 2004. The proclamation is followed by a list of over 130 names representing Slovakia's professional, cultural and political elite. The effect of this list of supporters is to demonstrate collective moral authority. Moving below to the area containing readers' remarks, however, one finds that what began as a serious discussion about the obligation of the state to protect natural and national resources suddenly devolves. At the seventh entry the whole narrative is sidelined by a single reader's remark claiming the futility of petitions and demanding that if people do not like living in the shadow of the US flag, then they should move to Belarus. Following this post, the remainder of the reader remarks effectively abandoned the cause of fighting deforestation to debate at length whether there is or is not a totalitarian regime in Belarus.

If reading and text-making are both acts, then we see how the blog genre is vulnerable to both of these dimensions of literacy. In a process that I call the 'degeneration of cause' we see that an activist's message is posted and circulated, and then quickly becomes part of another text-in-process, and one which may sway sharply from the original message. 
In still another sense, the individual status and identities of commentators who post replies on blogs may not be as important as the actual volume of commentary that accumulates following a particular post. For example, I was surprised to find the postings of older activists-people who were active in the environmental movement prior to 1989, like Mikuláš Huba—attracting more commentary than younger greens. If we compare for example the number of responses that Juraj Rizman receives with those garnered by Huba, Huba's average response rate comes to about 50 per post. Rizman gets a far lower 35. It appears from this example that some members of the older generation of greens have adapted quite well to the online world of cyberactivism. In contrast, other younger environmental organisations, such as Za matku Zem and Priatelia Zeme, have been less successful at pursuing the digital samizdat of the blog. For instance, a 2009 posting by Priatelia Zeme on 'www.changenet.sk' received not a single remark to their post on lifestyle and climate change (changenet.sk-Na skolach je prima klima-visited 28 September 2009). As another example, the present head of Za matku Zem, Pavel Široký, started a blog 'siroky.blog.sme.sk' on the newspaper SME's website in the fall of 2006. Posts continued up until the summer of 2007, and the site was dormant for three years, with the most recent update in November of 2010. Nevertheless, both young and older activists have begun to move to the digital realm, albeit as a gradual process with varying degrees of intensity and consistency.

\section{Discussion and conclusion}

The growing presence of Slovakia's environmental movement in the blogosphere raises all kinds of questions and suggests a whole range of areas for future research and avenues for theorising public and discursive space in the post-socialist transition. For example, has the internet begun to replace the public square as a venue for environmental protest? If, according to DeLuca's [1999] notion of the 'media event', the success or failure of contemporary environmental activism is marked by the public's uptake of an issue through its publicisation or 'coverage', then the internet can provide us with readily comparable data. No one would know whether thousands of visitors actually read Friends of the Earth's posting. Yet the commentary following Huba's and Rizman's pieces-taken as an image in itself-gives other readers a visible, almost physical sense that these texts have been read-,and since they were read, they must in some way count.

No doubt these actions in the digital realm, while similar in certain ways to the samizdat of the past,are, at the same time, far from the cultural and political contexts of the past that produced the unique genre of underground self-publication. In short, digital environmentalism - as is the case with many online textual formations-exists in a unique transition arena. The Slovak ecology movement has certainly moved far beyond the sphere of the brigade-with its symbolic practicality and utilitarian idealism. It is now also firmly engaged in the realm of the digitally discursive, virtual community of words, texts, and images. 
While the post-socialist era has produced unique experiences and struggles for economic, political, and cultural voices and identities [Humphrey 2000; Dunn 2006; Bunzl 2000] we might ask whether the internet is truly a medium through which these voices and identities can transcend the local constraints of place? Or is blogging a sort of samizdat that may prove to have relatively little power to inform, critique, and motivate large numbers of people in an age of neoliberalism? For example, while Wesch [2007] demonstrates how new areas of research and information-sharing are made possible through advances in digital technology that allow for novel knowledge-making practices and activities in the academy, Malaby [2009] has highlighted some of the limits that virtual communicative technologies present. In his study of building communities and commercial workspaces in the context of Second Life and Linden Lab, as these are constituted through networks and digital technologies, he shows how virtual worlds are not so much breaks with reality-i.e. transcendent products of culture-but arenas that continue to reproduce present cultural processes which are simply expressed in new ways. Other scholars have explored the cultural, economic and social aspects of online interaction and the potential and real inequalities that result from the interface of these industries and their users [Katz and Rice 2002; Hampton and Wellman 2003]. Targeting social media in particular, the journalist Malcolm Gladwell has criticised the supporters of networking sites like Facebook, Twitter, and MySpace, as well as the burgeoning number of blogs, for not recognising — or acknowledging — the very real limits of this technology as a force for activism [Gladwell 2010]. Recent research in the United States suggests that amidst the wealth of websites-the majority of users are visiting only those blogs that confirm their own beliefs and biases [Sunstein 2006]. In this sense blogging is more like an insular and self-serving form of connection with a public much unlike the extroverted and confrontational acts of public demonstration and civic protest.

To be fair, blogging about pollution and ecology is merely one form among many of environmentalist activities in post-socialist states like Slovakia. A growing body of research on environmental movements in the region suggests a rich array of social and political actions pursued in the name of ecology. ${ }^{9}$ At the same time, the aspects of blogging under criticism by scholars certainly apply beyond the Slovak case. Noting the rise of internet activity in Slovakia and in other postsocialist states, environmentalist blogging certainly appears to be part of a larger trend toward the growth of the inner lives of social movements. Maratea [2008] has recently examined this phenomenon in the context of the US blogosphere and its relationship with the promotion and articulation of social problems. Maratea argues that blogs may make the discursive establishment of an issue more efficient, extend the public reach of the issue more broadly and with more sustain, and that may enable outsider groups and individuals to participate in the defi-

\footnotetext{
9 See, for example, Fagan [2004], Harper [2006], Schwartz [2006], and Gille [2007].
} 
nition and dissemination of an issue as a social problem. ${ }^{10}$ But he also cautions that only a very small number of blogs ever attain mass recognition among the general public as a legitimate site for the production and promotion of key social issues of contemporary concern. In short, groups on the fringe, although they may be like-minded individuals and while they may be able to keep better track of their own community of conscience, remain on the fringe in the cyberworld.

If we compare this new discursive technology of digital self-publication to the old technology of samizdat, we see a possible disconnect between the inner and outer lives of civil society. In the late 1980s, Martin Bútora, the Slovak sociologist, suggested the notion of 'positive deviance' to describe the para-dissident nature of environmental activism [Bútora 1988; Bútora, Krivý and Szomolányiová 1989]. Under communism, samizdat became the portal to an alternative consciousness. Brigades were an officially acceptable practice in which the alternative world of samizdat could be discussed and debated. Civic volunteer activism thus became a performance of exposing the real world as a fiction [Snajdr 2008; Kenney 2003; Garton Ash 1990]. Dialogue was the result and in dialogue the regimes failed.

Perhaps what the internet now offers online is not only an easier path to information sharing among strangers or to increased collective action and coordination for social or political change, but also, and perhaps more commonly, a new kind of in-line-ness in the form of an increasing isolation of interests, issues and causes in the context of cyberspace and consequently in the real world. Such isolation is certainly not the self-censorship so keenly described by Slavenka Drakulić writing about Yugoslav communism where the people themselveswhom she refers to as 'our little Stasi' - policed each other's public actions and private beliefs [Drakulić 1993]. In the cyber-world, the blog offers the unique isolation of writing only in one's own space as if it were public. The burgeoning digital sphere in Slovakia-as well as elsewhere-has only some of the collective characteristics of a samizdat community and many of the characteristics of the neoliberal, self-reliant and self-selective paradigm of the late capitalist world [Harvey 2007; Seiler 2009]. The rise of the blogosphere in Slovakia's civil society begs the question of how we are now defining the public sphere and the individual who is at once situated within it and who may be oriented against and beyond it. After the collapse of communism, and with the death of traditional samizdat, there is no need for secret police. Rather what we see in cyberspace is a framework of engagement where, given the capacities and choices of the technology, people who are not interested in engaging in dialogues of difference simply refrain from doing so. There is certainly another website or blog to spend time with. On the other hand, I have tried to show some of the discursive possibilities

${ }^{10}$ The two case studies that Maratea uses for his analysis of US blogs are the Rathergate scandal in which George W. Bush's military service was questioned by CBS News and the Schiavo 'Talking Points' memo related to the right-to-life controversy [Maratea 2008: 149-155]. 
and implicit limitations of the medium of blogging in the context of Slovakia's environmental movement's engagement with online formats. Certainly these areas of digital discourse should open up more subjects for future research in terms of their implications for the development of ecological activism in the public sphere in Central and East Europe and beyond.

EDWARD SNAJDR is associate professor in the Anthropology Department at John Jay College, City University of New York. His research is focused on political and legal anthropology, environmentalism, gender violence, crime, ethnicity, and urban change. His monograph Nature Protests: The End of Ecology in Slovakia was published in 2008 by the University of Washington Press. His work on Slovak environmentalism has appeared in the journals Problems of Post-communism, Hungarian Studies, and the edited volumes Pink, Purple and Green: New Social Movements in Eastern Europe (Helena Flam, ed.) and Intellectuals and Politics in Central Europe (Andras Bozoki, ed.).

\section{References}

Bach, Jonathan and David Stark. 2003. 'Technology and Transformation: Facilitating Knowledge Networks in Eastern Europe. Technology, Business and Society Program.' Paper No. 10. Geneva: United Nations Research Institute for Social Development.

Bunzl, Matti. 2000. Altering States: Ethnographies of Transition in Eastern Europe and the Former Soviet Union. Ann Arbor, MI: University of Michigan Press.

Bútora, Martin. 1990. 'Vyvzdoruvanie alebo kazdodennost positivnych deviantov.' (The Resistance or Everydayness of Positive Deviance) Pp. 76-88 in Lesk a bieda každodennosti. M. Ac et al. Bratislava: Smena.

Bútora, M. Z. Bútorová and T. Rosová. 1991. 'The Hard Birth of Democracy in Slovakia.' Journal of Communist Studies 7 (4): 435-459.

Bútora, M., V. Krivý and S. Szomolányiová. 1989. 'Positive Deviance: The Career of a Concept in Czecho-slovakia in the late 1980s.' Unpublished manuscript.

Darnton, Robert. 1989. 'Toward a History of Reading.' The Wilson Quarterly. 13 (4): 86-103.

DeLuca, Kevin Michael. 1999. Image Politics: The New Rhetoric of Environmental Activism. Guildford: Guildford Press.

Doellinger, David. 2002. 'From Prayer to Protests: The Impact of Religious-Based Dissent in the Emergence of Civil Society in Slovakia and the GDR.' PhD dissertation, Department of History, University of Pittsburgh, Pittsburgh, PA.

Drakulić, Slavenka. 1993. How We Survived Communism and Even Laughed. New York: Harper Perennial.

Dunn, Elizabeth C. 2006. 'Standards of Person-making in East Central Europe.' Pp. 173-193 in Global Assemblages: Technology, Politics and Ethics, edited by A. Ong and S. J. Collier. London: Blackwell Publishing.

Fagan, Adam. 2004. Environment and Democracy in the Czech Republic: The Environmental Movement in the Transition Process. Cheltenham: Edward Elgar.

Garton Ash, Timothy. 1990. The Magic Lantern. New York: Random House.

Gille, Zsuzsa. 2007. From the Cult of Waste to the Trash Heap of History: The Politics of Waste in Socialist and Post-socialist Hungary. Bloomington, IN: Indiana University Press. 
Gladwell, Malcom. 2010. 'Small Change: Why the Revolution Will Not Be Tweeted.' The New Yorker, 4 October, pp. 42-49.

Hampton, Keith and Barry Wellman. 2003. 'Neighboring in Netville: How the Internet Supports Community and Social Capital in a Wired Suburb.' City E Community 2 (4): 277-311.

Harper, Krista. 2006. Wild Capitalism: Environmental Activists and Post-socialist Political Ecology in Hungary. New York: East European Monographs and Columbia University Press.

Harvey, David. 2007. A Brief History of Neoliberalism. New York: Oxford University Press.

Huba, Mikuláš. 2003. 'The Development of the Non-governmental Environmental Movement in Slovakia: The Slovak Union of Nature and Landscape Conservationists.' Pp. 92-104 in Local Communities and Post-communist Transformation: Czechoslovakia, the Czech Republic and Slovakia, edited by Simon Smith. London: Routledge.

Humphrey, Carolyn. 2000. The Unmaking of Soviet Life: Everyday Economics after Socialism. Ithaca, NY: Cornell University Press.

Johnston, Gordon. 1999. 'What Is the History of Samizdat?' Social History. 24 (2): 115-133.

Joo, Hyung-Min. 2004. 'Voices of Freedom: Samizdat.' Europe-Asia Studies 56 (4): 571-594.

Katz, James E. and Ronald E. Rice. 2002. Social Consequences of Internet Use. Cambridge, MA: The MIT Press.

Kenney, Padraic. 2003. A Carnival of Revolution: Central Europe 1989. Princeton, NJ: Princeton University Press.

Komaromi, Ann. 2004. 'The Material Existence of Soviet Samizdat.' Slavic Review 63 (3): 597-618.

Ludrovská, Katarina. 2008. Blogs in Slovakia: New Media and Freedom of Expression in Slovakia. Saarbrucken: Lambert Academic Publishing.

Malaby, Thomas. 2009. Making Virtual Worlds: Linden Lab and Second Life. Ithaca, NY: Cornell University Press.

Maratea, Ray. 2008. 'The E-Rise and Fall of Social Problems: The Blogosphere as a Public Arena.' Social Problems 55 (1): 139-160.

Podoba, Juraj. 1998. 'Rejecting Green Velvet: Transition, Environment and Nationalism in Slovakia.' Environmental Politics. 7 (1): 128-144.

Schwartz, Katrina. 2006. Nature and National Identity after Communism: Globalizing the Ethnoscape. Pittsburgh, PA: University of Pittsburgh Press.

Seiler, Cotton. 2009. 'Putting the Market in Its Places.' American Quarterly 61 (4): 943-953.

Snajdr, Edward. 1998. 'The Children of the Greens: New Ecological Activism in Post-socialist Slovakia.' Problems of Post-communism 45 (1): 54-62.

Snajdr, Edward. 2008. Nature Protests: The End of Ecology in Slovakia. Seattle, WA: University of Washington Press.

Snajdr, Edward. 2009. 'Two Landscapes: Comparing Ecology Movements in Slovakia and Hungary.' Hungarian Studies 23 (2): 211-222.

Sunstein, Cass. 2006. Infotopia: How Many Minds Produce Knowledge. New York: Oxford University Press.

Surman, Mark. 2002. 'Changenet.sk: Giving Voice to Slovak NGOs and Activists.' Understanding Civil Society Portals. Retrieved 1 June 2012 (http://www.commons. $\mathrm{ca} /$ articles / fulltext.shtml? $\mathrm{x}=423$ ).

Wesch, Michael. 2007. 'What is Web 2.0? What Does It Mean for Anthropology?' Anthropology News 48 (5): 30-31.

Wright, Patrick. 1990. 'Gesture Politics.' New Statesman and Society, 1 June, pp. 16-20.

Yakushev, Alexei. 1975. 'The Samizdat Movement in the USSR: A Note on Spontaneity and Organization.' Russian Review 34 (2): 186-193. 